\title{
Difference of opinion and the cross-section of equity returns: Australian
} evidence

\author{
Philip Gharghori, Quin See and Madhu Veeraraghavan
}

Department of Accounting and Finance, Monash University, VIC 3800, Australia.

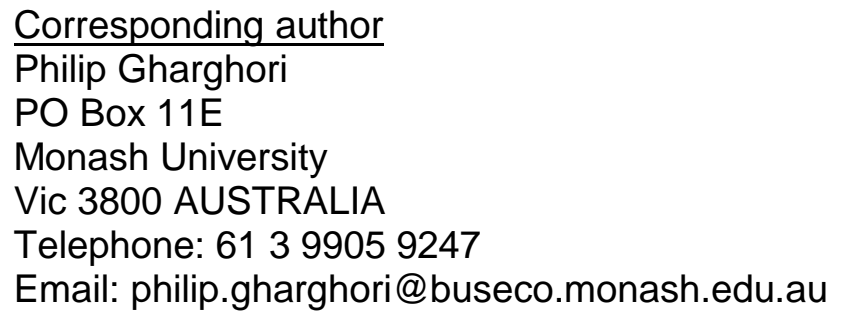




\title{
Difference of opinion and the cross-section of equity returns: Australian evidence
}

\begin{abstract}
This paper examines the relationship between difference of opinion among investors and the return on Australian equities. The paper is the first to employ dispersion in analysts' earnings forecasts and abnormal turnover as proxies for difference of opinion. We document a negative relationship between difference of opinion and stock returns when using dispersion in analysts' forecasts to proxy difference of opinion. This result provides support for Miller's (1977) model and is consistent with the findings of Diether et al. (2002). In contrast, we find mixed results when using abnormal turnover to proxy difference of opinion. In the second stage of our analysis, we augment the Carhart (1997) model with a difference of opinion factor and run asset pricing tests on the augmented model. Our findings suggest that the difference of opinion factor is not useful in pricing assets and that difference of opinion is not a proxy for risk.
\end{abstract}

EFM Classification: 310,350

JEL Classification: G10, G12, G15

Key Words: Difference of Opinion, Analysts' Earnings Forecasts, Abnormal Turnover 


\section{Introduction}

In an efficient stock market, future payoffs on assets cannot be predicted on the basis of available information. At least three decades ago financial economists believed that this assumption was true. Now, it is widely accepted that stock returns are at least partly predictable (see, for example, Fama 1991). A large body of empirical research over the past three decades has provided evidence against the prediction of the traditional Capital Asset Pricing Model (CAPM). This previous work shows that the cross-section of expected stock returns is not sufficiently explained by their market betas. It is well documented that factors such as firm size (Banz, 1981), earnings yield (Basu, 1977), leverage (Bhandari, 1988) and the firm's book value of equity to its market value (Chan, Hamao, and Lakonishok, 1991) explain the crosssection of average stock returns better than the beta of a stock. More recently, Diether, Malloy, and Scherbina (2002) document that firm's with more uncertain earnings do worse. Specifically, they show that high (low) dispersion in earnings expectations can predict low (high) stock returns in the future. In short, Diether et al. (2002) suggest that dispersion in analysts' earnings forecasts has a predictive power for future stock returns. These patterns are considered anomalies because they are not explained by the CAPM (Fama and French, 2008).

In a controversial paper, Miller (1977) hypothesized that stock prices will reflect the valuations of optimists but not of pessimists as pessimistic investors do not participate in the market due to short-sales constraints. Miller (1977) theorized that stocks that are subject to short-sale constraints become overvalued as pessimists are restricted to owning zero shares and thus the price is set by optimistic investors (Boehme, Danielsen and Sorescu 2006). Miller's hypothesis was based on the assumption that the most optimistic investors set stock prices. However, Diamond and Verrecchia (1987) challenge Miller (1977) by stating that short-sale constraints do not lead to overvaluation. Diamond and Verrecchia (1987) introduce a rational expectations model to analyse the effects of short-sale constraints on the speed of 
adjustment of stock prices. They report that although short-sale constraints can eliminate some informative trades, they do not have an upward bias on stock prices. They also document that if traders have rational expectations, short-sale constraints do not lead to biased prices. In a recent paper, Berkman, Dimitrov, Jain, Koch and Tice (2008) point out that Miller (1977)'s hypothesis that stock prices reflect an optimistic bias cannot persist indefinitely as periodic announcements reduce the differences of opinion among investors and thus stock prices move closer to their fundamental values.

As far as empirical support for Miller's (1977) hypothesis is concerned, Ackert and Athanasakkos (1997) document that high earnings forecast dispersion is associated with lower stock returns. This evidence is consistent with Miller's priceoptimism model that the greater the disagreement about a stock's value the higher its market price and hence the lower its future return. In a similar vein, Dische (2002) documents that a portfolio of high dispersion stocks yields a return of 0.80 percent per month while a portfolio of low dispersion stocks yields a return of 1.74 percent per month.

Diether et al. (2002) also document a negative relationship between difference of opinion and stock returns. They show that stocks with higher dispersion in analysts' earnings forecasts earn lower future returns than otherwise similar stocks. Specifically, they document that a portfolio of stocks in the highest quintile of dispersion underperforms a portfolio of stocks in the lowest quintile by 9.48 percent per year. They also report that this effect is most pronounced in small stocks and stocks that have performed poorly over the past 12 months. Their findings provide support for Miller (1977) and are contrary to the claim that dispersion in forecasts can be viewed as a proxy for risk. Further, Avramov, Chordia, Jostova and Philipov (2008) document that the dispersion effect is anomalous as investors seem to be 
paying a premium for bearing uncertainty about future profitability rather than discount uncertainty ${ }^{1}$.

Doukas, Kim, and Pantzalis (2002) advance difference of opinion as a plausible explanation for the abnormal return on value stocks. They document that value stocks display higher forecast errors and larger downward forecast revisions than growth stocks indicating that investor's are not excessively optimistic about growth stocks. In their 2004 paper, they investigate whether difference of opinion plays a role in asset pricing. They document that dispersion in analysts' earnings forecasts is considerably higher for high book-to-market stocks than for low book-tomarket stocks. That is, value stocks are associated with greater disagreement than growth stocks. Their findings suggest that difference of opinion represents risk not captured by the CAPM or by the multifactor model of Fama and French (1996) and that it plays an important role in explaining why value stocks generate superior returns than growth stocks. Park (2005) also shows that dispersion in analysts' earnings forecasts has strong predictive power for future stock returns but argues that this evidence should be interpreted as a measure of the differences in investors' expectations rather than proxy for risk.

Doukas, Kim and Pantzalis (2006a) examine whether divergence of opinion is priced at a premium or discount. They report a positive and significant relationship between divergence of opinion and future stock returns. Their findings contradict Miller (1977) but are consistent with Varian (1985) who argues that divergence of opinion proxies for risk. Doukas, Kim and Pantzalis (2006b) document that investors invest in low dispersion stocks when earnings expectations are optimistic and ignore low dispersion stocks when earnings expectations are pessimistic. They also show that overvaluation occurs when divergence is low and analyst's predictions are optimistic.

\footnotetext{
${ }^{1}$ They show that the negative relationship between dispersion in analysts' forecasts and stock returns exist only during periods of credit rating downgrades. In the remaining periods, they find the relationship to be insignificant.
} 
Garfinkel and Sokobin (2006) examine the relationship between post earnings announcement returns and unexplained trading volume (proxy for divergence of opinion) and report that unexpected trading volume at the earnings announcement positively correlates with future stock returns. Specifically, they show that high divergence of opinion at the earnings announcement date is associated with positive returns during the post announcement period. This finding is consistent with Varian (1985) who documents that asset prices will be lower when opinions are dispersed.

Hintikka (2008) tests Miller's (1977) hypothesis for equities listed in seven European countries and reports that stocks with lower dispersion in analysts' earnings forecasts generate superior returns than stocks with higher dispersion. In a similar vein, Leippold and Lohre (2008) find that high dispersion stocks not only underperform in the US but also in many European markets. They also report that in European markets most of the returns are generated in a narrow window of three years while the dispersion effect in the US displays a steady pattern. Hu, Ginger and Potter (2008) investigate opinion divergence among fund managers and show that opinion divergence when combined with short-sale constraints result in an upward bias in stock prices and subsequent low returns. This finding is consistent with the notion that when short-selling is constrained, prices will reflect the more optimistic valuations. Chang, Cheng and Yu (2007) investigate short-sale practices in Hong Kong and find that short-sale constraints cause stock overvaluation and that the overvaluation is greater when opinion divergence is wider. This finding is consistent with Miller's (1977) conjecture.

We can see from the above discussion that the evidence on whether difference of opinion represents risk is not only exiguous but also mixed and inconclusive. In addition, little empirical research has been conducted on how difference of opinion affects stock prices (Diether et al., 2002). Berkman et al. (2008) also highlight that testing Miller's conjecture on the role of difference of opinion is important as it challenges traditional asset pricing models such as the CAPM. In sum, 
prior research has not generated convincing evidence on the effects of difference of opinion on stocks prices.

Given this background, the central objectives of this paper are two-fold. First, we empirically test the relationship between difference of opinion and stock returns. Specifically, we are interested in determining the role of dispersion in analysts' earnings forecasts and abnormal turnover in predicting the cross-section of future stock returns for Australian equities. To do so, we perform a portfolio returns analysis, where stocks are grouped into portfolios based their level of opinion divergence, and a Fama-MacBeth (1973) regression analysis. Second, we seek to determine if a difference of opinion factor is useful in pricing assets and whether difference of opinion is a proxy for risk. We ask these questions as Avramov et al. (2008) note that the dispersion-return relation is unexplained by asset pricing models such as the CAPM and the Carhart (1997) model. We answer this question by augmenting the Carhart four-factor model with a difference of opinion factor and run asset pricing tests on this model. In this model, the difference of opinion factor is a zero cost portfolio that is long high difference of opinion stocks and short low difference of opinion stocks.

In summary, this paper not only attempts to understand the role of difference of opinion in predicting the cross-section of future stock returns but goes a step further by investigating whether difference of opinion represents risk not captured by the CAPM or the multifactor model of Fama and French (1996). Thus, our paper not only contributes to the literature on predictability of stock returns but also informs the current debate in the area of risk measurement techniques.

We study the Australian market for several reasons. First, asset pricing research done in Australia shows that there is much left to explain in the crosssectional variation in equity returns (Gharghori, Chan and Faff, 2007). Second, the Australian equity market is quite different from the US market. With over 1700 listed 
stocks and a market capitalization of $\$ 1220$ billion $^{2}$, the Australian market is much smaller than the US market. Further, the Australian market consists of different compositions of industries compared to the US. For example, two-thirds of the stocks listed on the ASX are represented by financials and materials companies ${ }^{3}$. Another striking feature of the Australian market is the heavier weighting on mining and resource stocks compared to the US ${ }^{4}$. The different size and unique features of the Australian market provide an entirely different setting than the US market. Third, we provide out of sample evidence on whether the dispersion effect is common across other markets or specific to the US market.

Our study makes two contributions. First, we employ multiple proxies for measuring difference of opinion among investors. In a recent paper, Berkman et al. (2008) emphasise that multiple proxies are essential, as a major challenge in testing the Miller hypothesis is to determine proxies that capture differences of opinion. The two proxies employed in this paper are (a) dispersion in analysts' earnings forecasts and (b) abnormal turnover. We adopt abnormal turnover because dispersion in analysts' earnings forecasts are biased toward large stocks, in that the analyst following for small stocks is thin or sometimes even non-existent. This results in an unrepresentative sample wherein the coverage for small stocks is limited. This problem was also faced by Hong and Stein (2000), Diether et al. (2002) and Doukas et al. (2004) .

Second, besides running individual regressions to test whether the difference of opinion factor is useful in pricing assets, we also adopt the generalized method of moments (GMM) system regression approach (MacKinlay and Richardson, 1991). Specifically, we augment the system with five additional equations, which enables us to estimate the factor premiums concurrently in the context of the overall system.

\footnotetext{
${ }^{2}$ Source: Australian Stock Exchange (ASX) Website as of August 2006

${ }^{3}$ Source: ASX Website

${ }^{4}$ Source: Australian Financial Review

${ }^{5}$ As an example, Diether et al. (2002)'s sample covers only $40.5 \%$ of total stocks listed in CRSP.
} 
Hence, the systems test that we employ presents a stronger test than the individual regressions, as it enables the estimation of the individual factor premiums for each factor of the asset pricing models.

We find a negative relationship between difference of opinion and stock returns, particularly when using analysts' forecasts to proxy opinion divergence. Our finding is consistent with Diether et al. (2002) and consequently provides support for Miller's (1977) model. In the asset pricing tests, we find that the difference of opinion factor is not useful for pricing assets and that difference of opinion is not a proxy for risk. The remainder of this paper proceeds as follows. Section 2 describes the data and methods employed in this paper. Section 3 presents the empirical findings, and section 4 concludes.

\section{Data and Methods}

\subsection{Data}

Our data come from five different sources. We obtain the monthly stock returns, market capitalisations, number of issued shares, industry classifications, the market return and the risk-free return from the Centre for Research in Finance (CRIF) database. The risk-free return is proxied by the monthly return on the 13-week Treasury note and is obtained from the Reserve Bank of Australia. The market return is proxied by the value-weighted market index constructed using all companies in the CRIF file. Accounting data required to calculate book equity (Net Tangible Assets) is obtained from Aspect Huntley. Standard deviation in monthly analyst forecasts and the mean of monthly analyst forecasts are collected from the Institutional Brokers Estimate System $(\mathrm{I} / \mathrm{B} / \mathrm{E} / \mathrm{S})$. Daily stock returns and volumes are obtained from SIRCA. Our sample covers the period from $1989-2005$ and the test period is $1990-$ 2005. 


\subsection{Methods}

There are three distinct stages in this analysis: 1) portfolio returns analysis, 2) Fama-MacBeth regressions and 3) asset pricing tests.

\subsubsection{Portfolio Returns Analysis}

The portfolio returns analysis is designed to provide preliminary evidence on whether there is a relationship between difference of opinion and equity returns. In this paper, two proxies are used for difference of opinion, dispersion in analysts' earnings forecasts and abnormal turnover. Dispersion in analysts' earnings forecasts is measured as the monthly standard deviation in analyst forecasts for a given stock divided by the absolute value of the mean of the monthly analyst forecasts. The reason that the standard deviation of forecasts is scaled by the mean is to make the analysis comparable across stocks as stocks that have higher earnings could have mechanically higher levels of standard deviation. Following, Diether et al. (2002), a stock must have a minimum of two analyst forecasts in a month to be included in the sample.

In each month, all stocks that have a valid dispersion measure are ranked based on difference of opinion and partitioned into quintiles (and tritiles). The equally weighted returns for these portfolios are calculated using returns in the following month. That is, monthly rebalancing is employed. The reason that monthly rebalancing is employed is that difference of opinion over stock value is more likely to change over a shorter period. In addition to calculating returns for the quintile and tritile portfolios, zero cost portfolios are also created that are long high difference of opinion stocks and short low difference of opinion stocks. The zero cost portfolio constructed from the tritile portfolios is used as the difference of opinion factor in the asset pricing tests. As a robustness test, we replicate the portfolio construction technique outlined above but only for companies that have the same fiscal year end. In our sample, approximately 70 per cent of companies have a June financial year 
end. Thus, the portfolios are re-created using the subset of companies that have June fiscal year ends. This is done to control for any seasonal variation in the standard deviation in analyst forecasts.

The second proxy employed to measure difference of opinion is abnormal turnover. Abnormal turnover is obtained by running monthly cross-sectional regressions of stock turnover on size, book-to-market and industry. Stock turnover is defined as monthly trading volume divided by number of issued shares. Size is proxied by market capitalisation and book-to-market is defined as net tangible assets divided by market capitalisation. For industry, 28 dummy variables are used to control for the 28 industry classifications specified by S\&P via GICS. Abnormal turnover is the residual from the aforementioned regression for each firm. The intuition for using abnormal turnover to proxy difference of opinion is to control for cross-sectional determinants of turnover that are unrelated to opinion divergence so as to isolate the component of turnover that captures difference of opinion. Similar to the portfolios created using dispersion in analysts' earnings forecasts, monthly rebalancing of the quintile (and tritile) portfolios is employed. The rationale is the same as before, difference of opinion as captured by abnormal turnover is most likely to be observed over a short time frame.

\subsubsection{Fama-MacBeth Regressions}

The Fama-MacBeth approach is the formal statistical test of the relationship between difference of opinion and returns. Following the same line of reasoning as before, difference of opinion, as proxied by both dispersion in analysts' earnings forecasts and abnormal turnover, is measured in a given month and linked with return data in the following month. That is, cross-sectional regressions of next month's stock returns on difference of opinion are performed each month.

As well as running regressions with difference of opinion as the sole independent variable, multiple regressions with size and book-to-market are also run 
to ascertain the robustness of any observed relationship between difference of opinion and equity returns. To be consistent with prior Australian research by Chan and Faff (2003), the log of size and book-to-market is taken. Following, Chan and Faff (2003), our cross-sectional regressions are estimated using Ordinary Least Squares adjusted for White's (1980) heteroskedasticity consistent covariance matrix and Weighted Least Squares is employed to infer the sign and significance of the time series of cross-sectional regression parameters. The multiple regression, which includes size and book-to-market, can be specified as follows:

$$
\mathrm{R}_{\mathrm{i}}=\gamma_{0}+\gamma_{1} \mathrm{DO}_{\mathrm{i}}+\gamma_{2} \ln \left(\mathrm{SIZE}_{\mathrm{i}}\right)+\gamma_{3} \ln \left(\mathrm{B} / \mathrm{M}_{\mathrm{i}}\right)+\varepsilon_{\mathrm{i}}
$$

where $R_{i}$ is next month's return, DO is difference of opinion, SIZE is size and B/M is book-to-market.

\subsubsection{Asset Pricing Tests}

Similar to Doukas et al. (2004), we augment the Carhart (1997) model with a difference of opinion factor (DOF) and run asset pricing tests on this model. As described earlier, the difference of opinion factor is a zero cost portfolio that is long the tritile of stocks that have high difference of opinion and short the tritile of stocks that have low difference of opinion. The construction of SMB and HML is in principle

consistent with Fama and French (1993) and the momentum factor (MOM) with Carhart (1997). More specifically, the construction of all three factors is the same as that employed by Gharghori, Chan and Faff (2007). The test portfolios are the excess returns on the standard 25 size and book-to-market sorted portfolios, which are also constructed following Gharghori, Chan and Faff (2007).

Our multi-factor model takes the following form: 


$$
r_{p t}=a_{p t}+b_{p} r_{m t}+s_{p} S M B_{t}+h_{p} H M L_{t}+m_{p} M O M_{t}+d_{p} D O F_{t}+e_{p t}
$$

where $r_{p t}$ is the excess monthly return of a test portfolio, that is the portfolio return in excess of the risk free return, $r_{\mathrm{mt}}$ is the excess monthly return of the market portfolio, $\mathrm{SMB}_{\mathrm{t}}$ is the monthly return on the zero cost portfolio for size, $\mathrm{HML}_{t}$ is the monthly return on the zero cost portfolio for book-to-market, $\mathrm{MOM}_{\mathrm{t}}$ is the monthly return on the zero cost portfolio for momentum and $\mathrm{DOF}_{\mathrm{t}}$ is the monthly return on the zero cost portfolio for difference of opinion.

The returns of each of the 25 size and book-to-market portfolios are individually regressed on the model specified above. By regressing each portfolio's returns against the model, we can ascertain whether DOF is significant in explaining equity returns. Besides running individual regressions on the 25 portfolios, we also employ the Generalised Method of Moments (GMM) system regression approach adopted by MacKinlay and Richardson (1991), Faff (2001) and Gharghori et al. (2007). The empirical modelling applied in this research is based on a Carhart (1997) model enhanced with difference of opinion. Our model can be shown as:

$$
E\left(r_{p}\right)=b_{p} E\left(r_{m}\right)+s_{p} E(S M B)+h_{p} E(H M L)+m_{p} E(M O M)+d_{p} E(D O F) .
$$

The empirical counterpart of this model is given by equation (2). We can augment the system to allow a direct estimation of the premia for the five risk factors:

$$
\begin{gathered}
r_{p t}=b_{p} r_{m t}+s_{p} S M B_{t}+h_{p} H M L_{t}+m_{p} M O M_{t}+d_{p} D O F_{t}+e_{p t} \\
r_{m t}=\lambda_{m}+e_{b t} \\
S M B_{t}=\lambda_{S M B}+e_{s t} \\
H M L_{t}=\lambda_{H M L}+e_{h t} \\
M_{\text {OOM }}=\lambda_{M O M}+e_{m t} \\
D O F_{t}=\lambda_{\text {DOF }}+e_{d t}
\end{gathered}
$$


where $p=1,2, \ldots, N$.

Equations (5) to (9) impose a mean adjusted transformation on the independent variables in equation (4). Upon rearrangement, the null hypothesis is effectively a test of whether the intercept term $a^{*}$ is equal to a non-zero restriction:

$H_{0}: a^{*}=b_{p} \lambda_{m}+s_{p} \lambda_{S M B}+h_{p} \lambda_{H M L}+m_{p} \lambda_{M O M}+d_{p} \lambda_{D O F}$

Since the intercept in equation (4) is restricted to zero, there exist $6 \mathrm{~N}+5$ sample moment equations and $5 N+5$ unknown parameters (i.e. $\phi=b_{1}, b_{2}, \ldots ., b_{N}$, $\left.s_{1}, s_{2}, \ldots, s_{N}, h_{1}, h_{2}, \ldots, h_{N}, m_{1}, m_{2}, \ldots, m_{N}, d_{1}, d_{2}, \ldots, d_{N}, \lambda_{m}, \lambda_{S M B}, \lambda_{H M L}, \lambda_{M O M}, \lambda_{D O F}\right)$. This means there are 6 sample moment conditions for each of $N$ test equations, as follows: (a) the mean regression error term is zero and the regression error term is orthogonal to each regressor, namely, to (b) $\mathrm{r}_{\mathrm{mt}}$; (c) $\mathrm{SMB}_{\mathrm{t}}$; (d) $\mathrm{HML}_{\mathrm{t}}$; (e) $\mathrm{MOM}_{\mathrm{t}}$; and (f) DOF $_{t}$. Thus, the GMM statistic involves $N$ over-identifying restrictions (distributed $\mathrm{XN}_{N}{ }^{2}$ ) and is given by:

$$
\mathrm{GMM}=(\mathrm{T}-\mathrm{N}-1)^{*} \mathrm{~g}_{\mathrm{T}}(\hat{\phi})^{\prime} \cdot \mathrm{S}_{\mathrm{T}}^{-1} \cdot \mathrm{g}_{\mathrm{T}}(\hat{\phi})
$$

where $g_{T}(\hat{\phi})=\frac{1}{T} \sum_{t=1}^{T} f_{t}(\hat{\phi})$, is the empirical moment condition vector; and

GMM is (asymptotically) distributed as a chi-square statistic with $\mathrm{N}$ degrees of freedom.

There are several advantages in employing the system regressions approach over individual regressions. First, the system regression allows us to concurrently estimate the factor premiums of each explanatory variable. This allows testing for significance of the premia for the specified factors: $\mathrm{H}_{0}: \lambda_{m}=0 ; \mathrm{H}_{0}: \lambda_{S M B}=0 ; \mathrm{H}_{0}: \lambda_{H M L}=$ $0 ; H_{0}: \lambda_{M O M}=0 ;$ and $H_{0}: \lambda_{D O F}=0$. According to Doukas et al. (2004), the factor premium of DOF should be positive and significant. However, Diether et al. (2002) 
suggest that the factor premium of DOF should be negative and significant. This approach allows us to directly test which of the conflicting findings of Doukas et al. (2004) and Diether et al. (2002) is supported. Second, the system regression allows us to perform regressions for all 25 portfolios simultaneously. The advantage here is that by observing the GMM statistic, it can be ascertained whether the specified regression model works on all 25 portfolios.

We also employ the Modified Likelihood Ratio Test (MLRT) in order to test whether DOF is useful in pricing assets. Specifically, the MLRT tests whether the 25 coefficients on DOF are jointly equal to zero. The MLRT test statistic used in our analysis is also adopted by Connor and Korajczyk (1988) and Faff (1992). The MLRT can be shown as:

$$
M L R T=T^{*}\left\{\left[\frac{\operatorname{det}\left(\hat{\sum} r\right)}{\operatorname{det}\left(\hat{\sum} u\right)}\right]-1\right\}
$$

where

$\operatorname{det}\left(\hat{\sum} r\right)=$ the determinant of the maximum likelihood estimate of the error covariance matrix from the restricted system, $\operatorname{det}\left(\hat{\sum} u\right)=$ the determinant of the maximum likelihood estimate of the error covariance matrix from the unrestricted system, $\mathrm{T}^{*}=(\mathrm{T}-\mathrm{K}-\mathrm{N}) / \mathrm{N} ; \mathrm{T}=$ the number of time series observations, $\mathrm{K}=$ the number of factors, and $\mathrm{N}=$ the number of equations in the multivariate regression system.

This statistic is identical to the statistic described in Gibbons, Ross, and Shanken (1986). Given the assumption of normality, the MLRT has an exact small-sample F 
distribution with $(\mathrm{N}, \mathrm{T}-\mathrm{K}-\mathrm{N})$ degrees of freedom. The null hypothesis for the case of zero joint mispricing is:

$$
H_{0}: d_{p}=0 ; p=1,2, \ldots, 25
$$

If the null hypothesis is not rejected, this implies that in the context of the entire system, DOF has no ability to price the test portfolios. In the situation that the null hypothesis is rejected, DOF is useful in pricing the test assets.

\section{Empirical Findings}

\subsection{Descriptive Statistics}

Table 1 reports the descriptive statistics obtained by our study. The timeseries means for the market factor ( $0.38 \%$ per month), SMB (3.33\% per month), HML ( $0.87 \%$ per month), and MOM $(0.87 \%$ per month) are all positive and significant. The mean for DOF (constructed using dispersion in analysts' earnings forecasts) is negative and significant $(-0.36 \%$ per month). In contrast, the mean for DOF (constructed using abnormal turnover) is positive $(0.10 \%$ per month) albeit insignificant. The negative mean for DOF (using dispersion in analysts' forecasts) indicates that stocks with high difference of opinion underperform stocks with low difference of opinion. Our results in this respect are consistent with Miller (1977) and Diether et al. (2002). However, this finding is not corroborated by the alternate proxy for difference of opinion constructed using abnormal turnover.

\section{[Insert Table 1 about here]}

\subsection{Returns for Difference of Opinion Sorted Portfolios}

We sort stocks into quintiles (and tritiles) based on our two measures of difference of opinion, dispersion in analysts' earnings forecasts and abnormal 
turnover. The results are reported in Table 2. In Panel A, we report returns using dispersion in analysts' forecasts as a proxy for difference of opinion. Panel B also reports returns using dispersion in analysts' forecasts but only for stocks that have a June financial year end. In Panel C, we use abnormal turnover to proxy difference of opinion. Panel A shows that a zero cost portfolio (Q5 - Q1) that is long high difference of opinion stocks and short low difference of opinion stocks generates negative returns and that the return differential is statistically significant $(-0.54 \%$ per month). We also show that a zero cost portfolio based on tritile groupings ( $\mathrm{T} 3-\mathrm{T} 1$ ) generates significantly negative returns $(-0.36 \%$ per month). These findings are consistent with Miller (1977) and Diether et al. (2002). In Panel B, we report similar findings for stocks that have a June financial year end. In fact, the negative relationship is even stronger for firms that have a June financial year end. In Panel C, we show that $(\mathrm{Q} 5-\mathrm{Q} 1)$ and $(\mathrm{T} 3-\mathrm{T} 1)$ generate positive returns but they are not statistically significant. Thus, for the portfolio returns analysis, there is a negative relationship observed between dispersion in analysts' forecasts and returns but there is no statistically significant relationship observed between abnormal turnover and returns.

\section{[Insert Table 2 about here]}

\subsection{Fama-Macbeth Regressions}

In this section, we perform Fama-Macbeth cross-sectional regressions of future stock returns on difference of opinion, firm size and book-to-market. We are interested in determining if these variables have the ability to predict stock returns. The regression results are reported in Table 3. Panel A uses dispersion in analysts' earnings forecasts as a proxy for difference of opinion. Panel B also employs dispersion in analysts' earnings forecasts as a proxy but only includes firms that have a June financial year end. In Panel C, we report the results for abnormal turnover as 
the difference of opinion proxy. In each panel, we report results for regressions with difference of opinion as the sole independent variable and multiple regressions with firm size and book-to-market to ascertain the robustness of any observed relationship between difference of opinion and stock returns.

Our findings (Panel A) show that the relationship between difference of opinion (measured by dispersion in analysts' earnings forecasts) and returns is negative and highly significant. We also find that the relationship between firm size and returns is positive and significant but that the relationship between book-tomarket and returns is insignificant. In fact, we find that difference of opinion is the strongest variable (t-stat of -5.57 ) in predicting returns relative to firm size and bookto-market. The results for Panel B are similar to Panel A in that the relationship between difference of opinion and returns is negative and statistically significant, firm size has a positive and significant relationship with returns, and book-to-market is insignificantly related to returns. The similar results are not surprising though as the sample of firms with June financial year ends is approximately 70 per cent of the full sample. It also indicates that the negative relationship observed between difference of opinion and returns is robust to seasonal issues associated with firms having differing financial year ends. Panel $\mathrm{C}$ reports the results for abnormal turnover as the difference of opinion proxy. Our findings for Panel $C$ are similar to Panels $A$ and $B$ in that the relationship between difference of opinion and returns is negative and statistically significant. We also find that the relationship between returns and both firm size and book-to-market is positive and significant. Thus, the Fama-MacBeth regressions provide conflicting conclusions on the relationship between abnormal turnover and returns in comparison to the portfolio returns analysis. In the portfolio returns analysis, there was no significant relationship observed between abnormal turnover and returns. In contrast, in the Fama-MacBeth regressions, a significantly negative relationship is observed. Hence, in the Fama-MacBeth analysis there is a 
negative relationship observed between both difference of opinion proxies and returns. Further, this relationship is robust to the effects of size and book-to-market.

\section{[Insert Table 3 about here]}

\subsection{Difference of Opinion Augmented Carhart Regressions}

Table 4 reports the results of the 25 individual regressions of the DOF (using dispersion in analysts' forecasts) augmented Carhart model. The factor loading on the market portfolio, $b_{p}$, is close to or greater than one and statistically significant for all 25 portfolios. The factor loading on SMB, $s_{p}$, is significant for 20 out of 25 portfolios. We find that the coefficient on SMB is positive and significant for small portfolios and diminishing positive or negative for big portfolios. The factor loading on HML, $h_{p}$, is significant for nine out of 25 portfolios. Our findings also show that the factor loading for momentum, $m_{p}$, is significant for only four out of 25 portfolios. The factor loading on DOF (constructed using dispersion in analysts' forecasts), $d_{p}$, is insignificant for all 25 portfolios. This indicates that the difference of opinion factor is not useful in pricing assets. For further evidence in this regard, the unreported average adjusted $\mathrm{R}^{2}$ for the Carhart model is $55.7 \%$, whereas the average adjusted $\mathrm{R}^{2}$ for the DOF augmented Carhart model is $55.6 \%$.

\section{[Insert Table 4 about here]}

\subsection{System Regressions}

Table 5 reports the results of the GMM system estimation and the tests of the Fama-French, Carhart and DOF augmented Carhart models. The first system regression reported is for the Fama-French model. Our results show that the GMM statistic is insignificant, which supports the overall favourability of the Fama-French model. We find that the market premium $\left(\lambda_{m}\right)$ is positive and statistically significant (t- 
statistic of 2.44). Similarly, the factor premiums for SMB and HML are also positive and significant (t-statistic of 8.15 for $\lambda_{S M B}$ and 2.64 for $\lambda_{H M L}$ ). The positive and significant factor premiums for SMB and HML indicate that the Fama-French factors could be capturing some form of risk.

\section{[Insert Table 5 about here]}

The second system regression reported in Table 5 is for the Carhart model. An interesting finding here is that the inclusion of the momentum factor (MOM) results in the market premium $\left(\lambda_{\mathrm{m}}\right)$ becoming insignificant (t-statistic of 1.90). However, the premiums for SMB and HML remain positive and significant (t-statistic of 7.31 for $\lambda_{S M B}$ and 3.66 for $\lambda_{H M L}$ ) even after the inclusion of the MOM factor. The premium for the momentum factor $\left(\lambda_{\mathrm{MOM}}\right)$ is also positive and statistically significant (t-statistic of 3.47). Our findings show that the GMM statistic is insignificant for the Carhart model. Similar to the Fama-French model, the insignificant GMM statistic implies that the GMM test supports the overall favourability of the Carhart model.

The third system regression in Table 5 is for the Carhart DOF (DAF) model, where dispersion in analysts' forecasts is used to proxy opinion divergence. Similar to the previous two models, we find that the GMM statistic is insignificant (t-statistic 0.104). Our results show that the premium for the overall market factor is positive albeit insignificant. In contrast, the premiums for the size, book-to-market and momentum factors are significantly positive. The factor premium for DOF $\left(\lambda_{\mathrm{DOF}}\right)$ is negative and statistically significant (t-statistic of -2.17$)$. This result is consistent with the portfolio returns analysis and the Fama-MacBeth analysis. Moreover, the negatively significant factor premium indicates that difference of opinion is not a proxy for risk.

The fourth system regression reported in Table 5 is for the Carhart DOF (DAF-June) model, where DOF is created using stocks that have a June financial 
year end and where dispersion in analysts' forecasts is the difference of opinion proxy. Once again, we observe that the premium for the overall market factor is positive but insignificant (t-statistic 1.80). The factor premiums for SMB, HML, and MOM are positive and significant. Again, we find that the premium for DOF $\left(\lambda_{\mathrm{DOF}}\right)$ is negative and significant. Similar to the previous regression, this implies that DOF is not a priced risk factor in equity returns.

The final system regression reported is for the Carhart DOF (AT) model, where abnormal turnover is used to proxy difference of opinion. Our results show that the factor premiums for the overall market factor, size, book-to-market and momentum are positive and significant. The factor premium for the difference of opinion factor is also positive albeit insignificant, which again suggests that difference of opinion is not a proxy for risk. The last column in Table 5 reports the results from the Modified Likelihood Ratio Test (MLRT) for the DOF augmented Carhart models. The p-values for the Carhart DOF (DAF) and Carhart DOF (DAF-June) models show that the null hypothesis, $H_{0}: d_{p}=0$, cannot be rejected. This implies that DOF (constructed using dispersion in analysts' forecasts) is not useful in pricing assets. Considering that the MLRT is a joint test on 25 parameters, the fact that the null hypothesis has not been rejected is strong evidence against the usefulness of the factor in pricing assets. This is consistent with the findings in Table 4 where all 25 parameters on DOF $\left(d_{p}\right)$ were insignificant. In contrast, the MLRT when abnormal turnover is the difference of opinion proxy does reject the hypothesis that all 25 parameters are equal to zero. This suggests that DOF (constructed using abnormal turnover) is somewhat useful in pricing assets. In unreported results though where the regressions in Table 4 where re-run with the abnormal turnover factor replacing the dispersion in analysts' forecasts factor, only 5 of the 25 parameters on DOF were significantly different from zero. Thus, we down weight the finding of the MLRT when abnormal turnover is the difference of opinion proxy. 


\section{Conclusions}

Previous empirical research conducted in the US on the relationship between difference of opinion and stock returns have yielded mixed results. This paper provides out of sample evidence on the relationship between difference of opinion and stock returns. It makes two contributions. First, the study employs multiple proxies (dispersion in analysts' earnings forecasts and abnormal turnover) for measuring difference of opinion among investors. Second, it adopts a system regression approach to test the usefulness of a difference of opinion factor in explaining asset prices and to examine whether the difference of opinion factor is a priced risk factor

Overall, the results document a significant negative relation between difference of opinion (using dispersion in analysts' earnings forecasts as proxy) and stock returns. This result provides support for Miller's (1977) hypothesis and is consistent with the findings of Diether et al. (2002). For the abnormal turnover proxy, the findings are mixed. The portfolio returns analysis suggests that the relationship between abnormal turnover and returns is insignificant whereas the more formal Fama-MacBeth analysis suggests that the relationship is negative. In the asset pricing tests, we find that difference of opinion is not useful in pricing assets and that difference of opinion is not a proxy for risk. 


\section{References}

Ackert, L.F., Athanassakos, G., 1997. Prior uncertainty, analyst bias and subsequent abnormal returns. Journal of Financial Research 20, 263-273.

Avramov, D., Chordia, T., Jostova, G., Philipov, A., Dispersion in analysts' earnings forecasts and credit rating. Journal of Financial Economics (forthcoming)

Australian Financial Review website: www.afr.com.au

ASX website: www.asx.com.au

Banz, R.W., 1981. The relationship between return and market value of common stocks. Journal of Financial Economics 9, 3-18.

Basu, S., 1983. The relationship between earnings yield, market value, and return for NYSE common stocks: Further evidence. Journal of Financial Economics 12, 129-156.

Berkman, H., Dimitrov, V., Jain, P.C., Koch, P.D., Tice, S., Sell on the news: Difference of opinion, short-sales constraints and returns around earnings announcements. Journal of Financial Economics (forthcoming)

Bhandari, L.C., 1988. Debt/Equity ratio and expected common stock returns: Empirical evidence. Journal of Finance 43, 507-528.

Boehme, R.D., Danielsen R., Sorescu S.M., 2006. Short-sale constraints and overvaluation. Journal of Financial and Quantitative Analysis 41, 455-488.

Carhart, M., 1997. On persistence in mutual fund performance. Journal of Finance $52,57-82$.

Chan, H.W.H., Faff, R.W., 2003. An investigation into the role of liquidity in asset pricing: Australian evidence. Pacific-Basin Finance Journal 11, 555-572.

Chan, L.K.C., Hamao, Y., Lakonishok, J., 1991. Fundamentals and stock returns in Japan. Journal of Finance, 1739-1789.

Chang, E.C., Cheng, J.W., Yu, Y., 2007. Short-sales constraints and price discovery: Evidence from the Hong Kong market. Journal of Finance 62, 2097-2122.

Connor, G., Korajczyk, R.A., 1988. Risk and return in an equilibrium APT. Journal of Financial Economics 21, 255-289.

Diamond, D., Verrecchia, R., 1987. Constraints on short-selling and asset price adjustment to private information. Journal of Financial Economics 18, 277311.

Diether, K., Malloy, C., Scherbina, A., 2002. Differences of opinion and the cross section of stock returns. Journal of Finance 57, 2113-2141.

Dische, A., 2002. Dispersion in analyst forecasts and the profitability of earnings momentum strategies. European Financial Management 8, 211-228. 
Doukas, J., Kim, C., Pantzalis, C., 2002. A test of the error-in-expectations explanation of the value/glamour stock returns performance: Evidence from analysts' forecasts. Journal of Finance 57, 2143-2165.

Doukas, J., Kim, C., Pantzalis, C., 2004. Divergent opinions and the performance of value stocks. Financial Analysts Journal 60, 55-64.

Doukas, J., Kim, C., Pantzalis, C., 2006a. Divergence of opinion and equity returns. Journal of Financial and Quantitative Analysis 41, 573-606.

Doukas, J., Kim, C., Pantzalis, C., 2006b. Divergence of opinion and equity returns under different states of earnings expectations. Journal of Financial Markets 9, 310-331.

Faff, R.W., 1992. A multivariate test of an equilibrium APT with time varying risk premia in the Australian equity market. Australian Journal of Management 17, 233-258.

Faff, R.W., 2001. An examination of the Fama and French three-factor model using commercially available factors. Australian Journal of Management 26, 1-12.

Fama, E., 1991. Efficient capital markets II. Journal of Finance 36, 1575-1617.

Fama, E., French, K., 1993. Common risk factors in the returns on stocks and bonds. Journal of Financial Economics 33, 3-56.

Fama, E., French, K., 1996. Multifactor explanations of asset pricing anomalies. Journal of Finance 51, 55-84.

Fama, E., French, K., 2008. Dissecting anomalies. Journal of Finance 63, 16531678.

Fama, E., MacBeth J., 1973. Risk, return and equilibrium: Empirical tests. Journal of Political Economy 81, 607-636.

Garfinkel, J.A., Sokobin, J., 2006. Volume, opinion divergence and returns: A study of post-earnings announcement drift. Journal of Accounting Research 44, 85112.

Gharghori, P., Chan, H.W.H., Faff, R.W., 2007. Are the Fama-French factors proxying default risk? Australian Journal of Management 32, 223-249.

Gibbons, M.R., Ross, S.A., Shanken, J., 1986. A test of the efficiency of a given portfolio. Working Paper, Stanford University.

Hintikka, M., 2008. Market reactions to differences of opinion. Working Paper, The Swedish School of Economics and Business Administration.

Hong, H., Stein, J., 2000. Bad news travels slowly: Size, analyst coverage, and the profitability of momentum strategies. Journal of Finance 55, 265-295.

Hu, G., Ginger, M., Potter, M., 2008. Opinion divergence among professional investment managers. Journal of Business Finance and Accounting 35, 679703. 
Leippold, M., Lohre, H., 2008. The dispersion effect in international stock returns. Working Paper, Imperial College, London.

MacKinlay, A.C., Richardson, M., 1991. Using generalized method of moments to test mean-variance efficiency. Journal of Finance 46, 511-527.

Miller, E.M., 1977. Risk, uncertainty, and divergence of opinion. Journal of Finance $32,1151-1168$

Park, C., 2005. Stock return predictability and the dispersion in earnings forecasts. Journal of Business 78, 2351-2375.

Varian, H.R., 1985. Divergence of opinion in complete markets: A note. Journal of Finance 40, 309-317.

White, H., 1980. A heteroskedasticity-consistent covariance matrix estimator and a direct test for heteroskedasticity. Econometrica 48, 817-838. 
Table 1

Descriptive Statistics

\begin{tabular}{lllrrrr}
\hline & $r_{m}$ & \multicolumn{1}{l}{ SMB } & \multicolumn{1}{l}{$\mathrm{HML}$} & \multicolumn{1}{c}{ MOM } & DOF (DAF) & DOF (AT) \\
\hline Mean & 0.0038 & 0.0333 & 0.0087 & 0.0087 & -0.0036 & 0.0010 \\
Mean Std. Error & 0.0024 & 0.0049 & 0.0035 & 0.0038 & 0.0021 & 0.0022 \\
t-statistic & 1.5659 & 6.7568 & 2.5260 & 2.2766 & -1.6869 & 0.4467 \\
Median & 0.0080 & 0.0214 & 0.0076 & 0.0086 & -0.0023 & 0.0025 \\
Maximum & 0.0731 & 0.3645 & 0.2989 & 0.1781 & 0.0731 & 0.0936 \\
Minimum & -0.1059 & -0.2029 & -0.1777 & -0.3352 & -0.0897 & -0.1278 \\
Std. Dev. & 0.0334 & 0.0684 & 0.0479 & 0.0532 & 0.0294 & 0.0300 \\
Skewness & -0.5851 & 1.1101 & 1.4387 & -1.3229 & -0.1245 & -0.6992 \\
Kurtosis & 3.3118 & 6.4093 & 13.9789 & 11.6622 & 3.2131 & 6.0387 \\
\hline
\end{tabular}

This table reports basic descriptive statistics for the six factors used in this analysis for the period 1990 to 2005. $r_{m}$ is the monthly excess return of the value-weighted market portfolio. SMB, HML and MOM are the monthly returns on the zero cost portfolios for size, book-tomarket and momentum, respectively. DOF (DAF) and DOF (AT) are the monthly returns on the zero cost portfolios for the difference of opinion factor constructed using dispersion in analysts' earnings forecasts and abnormal turnover, respectively. Difference of opinion factors are long high difference of opinion stocks and short low difference of opinion stocks based on tritile groupings as defined in Table 2 . 
Table 2

Returns for Difference of Opinion Sorted Portfolios

\begin{tabular}{|c|c|c|c|c|c|c|}
\hline Q1 & Q2 & Q3 & Q4 & Q5 & Q5 - Q1 & T3 - T1 \\
\hline \multicolumn{7}{|c|}{ Panel A: Dispersion in Analysts' Earnings Forecasts } \\
\hline 0.0090 & 0.0104 & 0.0093 & 0.0091 & 0.0037 & -0.0054 & -0.0036 \\
\hline$(3.20)$ & $(4.47)$ & $(3.51)$ & $(2.85)$ & $(0.90)$ & $(-2.04)$ & $(-1.69)$ \\
\hline \multicolumn{7}{|c|}{ Panel B: Dispersion in Analysts' Earnings Forecasts: June Financial Year End Only } \\
\hline 0.0105 & 0.0095 & 0.0066 & 0.0078 & 0.0017 & -0.0088 & -0.0071 \\
\hline$(3.55)$ & $(3.71)$ & $(2.31)$ & $(2.44)$ & $(0.39)$ & $(-2.79)$ & $(-3.01)$ \\
\hline \multicolumn{7}{|c|}{ Panel C: Abnormal Turnover } \\
\hline 0.0188 & 0.0146 & 0.0119 & 0.0136 & 0.0218 & 0.0030 & 0.0010 \\
\hline$(3.55)$ & $(3.46)$ & $(3.47)$ & $(4.27)$ & $(4.85)$ & $(1.16)$ & $(0.45)$ \\
\hline
\end{tabular}

This table presents returns for difference of opinion sorted portfolios. Every month, stocks are sorted into quintiles and (tritiles) based on difference of opinion. Equally weighted portfolio returns are calculated based on these rankings using returns in the following month. For a stock to be included in the portfolios, it must have a valid difference of opinion measure in the month of portfolio formation and a valid return measure in the following month. The reported values are the time-series average of the monthly portfolio returns over the sample period 1990 - 2005. T-statistics are reported directly below the portfolio returns in parentheses. Q1 to $Q 5$ represent the returns from the lowest difference of opinion quintile (Q1) to the highest quintile (Q5). Q5 - Q1 is the return of a zero cost portfolio that is long high difference of opinion stocks and short low difference of opinion stocks. Similarly, T3 - T1 is also a zero cost portfolio but is based on tritile groupings rather than quintiles.

Panel A reports returns using dispersion in analysts' earnings forecasts as a proxy for difference of opinion. Dispersion in analysts' earnings forecasts is the standard deviation of all analyst forecasts for a given stock reported in $\mathrm{I} / \mathrm{B} / \mathrm{E} / \mathrm{S}$ for a given month scaled by the absolute value of the mean of those forecasts. A stock must have a minimum of two analyst forecasts in a month to be included in the sample. Panel $B$ also reports returns using dispersion in analyst forecasts as a difference of opinion proxy. However, in Panel B, only stocks that have a June financial year end are included in the sample. In Panel $\mathrm{C}$, abnormal turnover is used to proxy difference of opinion. Abnormal turnover is obtained by running monthly cross-sectional regressions of stock turnover on size, book-to-market and industry. Stock turnover is defined as monthly trading volume divided by number of issued shares. Size is proxied by market capitalisation. Book-to-market is Net Tangible Assets divided by market capitalisation. 28 dummy variables are used to control for the 28 industry classifications specified by S\&P via GICS. Abnormal turnover is the residual from the aforementioned regression for each firm. 
Table 3

Fama-MacBeth Regressions of Monthly Stock Returns on Difference of Opinion, Size and Book-to-Market Equity

\begin{tabular}{|c|c|c|c|}
\hline Constant & DO & Size & $\mathrm{B} / \mathrm{M}$ \\
\hline \multicolumn{4}{|c|}{ Panel A: Dispersion in Analysts' Earnings Forecasts } \\
\hline $\begin{array}{r}0.0078 \\
(3.19)\end{array}$ & $\begin{array}{r}-0.0004 \\
(-5.42)\end{array}$ & & \\
\hline-0.0419 & -0.0005 & 0.0024 & 0.0009 \\
\hline$(-2.89)$ & $(-5.57)$ & $(3.65)$ & $(1.16)$ \\
\hline \multicolumn{4}{|c|}{ Panel B: Dispersion in Analysts' Earnings Forecasts: June Financial Year End Only } \\
\hline 0.0070 & -0.0005 & & \\
\hline$(2.80)$ & $(-4.50)$ & & \\
\hline-0.0366 & -0.0005 & 0.0022 & -0.0003 \\
\hline$(-2.28)$ & $(-3.86)$ & $(2.90)$ & $(-0.34)$ \\
\hline \multicolumn{4}{|c|}{ Panel C: Abnormal Turnover } \\
\hline-0.0018 & -0.0013 & & \\
\hline$(-0.52)$ & $(-2.44)$ & & \\
\hline-0.0250 & -0.0013 & 0.0016 & 0.0068 \\
\hline$(-1.54)$ & $(-2.57)$ & $(2.08)$ & $(7.38)$ \\
\hline
\end{tabular}

This table reports average Fama-MacBeth regression estimates using individual firm data for all months of our sample period - 1990 to 2005. In each month, a cross-sectional regression is estimated using OLS adjusted for White's heteroskedasticity-consistent covariance matrix, wherein next month's return is regressed on the variables specified. The values reported in the table are the average time-series slope estimates, which are obtained using Weighted Least Squares. The monthly slope estimates are weighted by the inverse of their standard error thereby giving more importance to slope estimates that are more precisely estimated. The associated t-statistics are reported in parentheses directly under the relevant mean slope estimate. DO is difference of opinion, Size is size and B/M is book-to-market. Panel A uses dispersion in analysts' earnings forecasts as a proxy for difference of opinion. Panel B also employs dispersion in analysts' earnings forecasts as the difference of opinion proxy but only includes firms that have a June financial year end. In Panel $C$, abnormal turnover is the difference of opinion proxy. 
Table 4

Individual Regressions of a Difference of Opinion Augmented Carhart Model on 25 Size- and Book-to-Market-Sorted Portfolios

\begin{tabular}{|c|c|c|c|c|c|c|c|c|}
\hline Size & $\mathrm{B} / \mathrm{M}$ & $a_{p}$ & $b_{p}$ & $s_{p}$ & $h_{p}$ & $m_{p}$ & $d_{p}$ & Adj $R^{2}$ \\
\hline 1 & 1 & $\begin{array}{r}0.0293 \\
(3.39)\end{array}$ & $\begin{array}{r}1.4796 \\
(6.54)\end{array}$ & $\begin{array}{l}1.1707 \\
(10.39)\end{array}$ & $\begin{array}{r}-0.4123 \\
(-2.77)\end{array}$ & $\begin{array}{r}0.1755 \\
(1.02)\end{array}$ & $\begin{array}{r}0.1108 \\
(0.43)\end{array}$ & 0.459 \\
\hline 1 & 2 & $\begin{array}{c}0.018 \\
(2.22)\end{array}$ & $\begin{array}{r}1.0485 \\
(4.52)\end{array}$ & $\begin{array}{r}1.4639 \\
(11.52)\end{array}$ & $\begin{array}{r}-0.1416 \\
(-0.65)\end{array}$ & $\begin{array}{c}0.139 \\
(1.16)\end{array}$ & $\begin{array}{r}0.0781 \\
(0.31)\end{array}$ & 0.551 \\
\hline 1 & 3 & $\begin{array}{r}0.0379 \\
(4.45)\end{array}$ & $\begin{array}{r}0.9957 \\
(4.01)\end{array}$ & $\begin{array}{l}1.2782 \\
(11.38)\end{array}$ & $\begin{array}{r}-0.4228 \\
(-1.82)\end{array}$ & $\begin{array}{r}-0.1079 \\
(-0.66)\end{array}$ & $\begin{array}{r}0.0824 \\
(0.30)\end{array}$ & 0.463 \\
\hline 1 & 4 & $\begin{array}{r}0.0117 \\
(2.10)\end{array}$ & $\begin{array}{r}1.3308 \\
(8.77)\end{array}$ & $\begin{array}{c}1.2527 \\
(10.95)\end{array}$ & $\begin{array}{r}0.1906 \\
(1.02)\end{array}$ & $\begin{array}{r}0.2796 \\
(2.37)\end{array}$ & $\begin{array}{r}0.1022 \\
(0.60)\end{array}$ & 0.641 \\
\hline 1 & 5 & $\begin{array}{r}0.0164 \\
(1.44)\end{array}$ & $\begin{array}{r}0.9159 \\
(3.82)\end{array}$ & $\begin{array}{l}1.611 \\
(5.90)\end{array}$ & $\begin{array}{l}1.425 \\
(2.13)\end{array}$ & $\begin{array}{r}-0.3283 \\
(-1.51)\end{array}$ & $\begin{array}{r}-0.2921 \\
(-1.03)\end{array}$ & 0.594 \\
\hline 2 & 1 & $\begin{array}{r}0.0064 \\
(1.09)\end{array}$ & $\begin{array}{r}1.1136 \\
(5.80)\end{array}$ & $\begin{array}{r}0.9486 \\
(9.11)\end{array}$ & $\begin{array}{r}-0.8059 \\
(-3.96)\end{array}$ & $\begin{array}{r}-0.1665 \\
(-1.69)\end{array}$ & $\begin{array}{r}-0.1487 \\
(-0.79)\end{array}$ & 0.598 \\
\hline 2 & 2 & $\begin{array}{r}0.0017 \\
(0.31)\end{array}$ & $\begin{array}{r}0.9119 \\
(6.68)\end{array}$ & $\begin{array}{l}1.064 \\
(9.30)\end{array}$ & $\begin{array}{r}-0.1095 \\
(-0.64)\end{array}$ & $\begin{array}{l}0.043 \\
(0.50)\end{array}$ & $\begin{array}{r}0.1468 \\
(0.84)\end{array}$ & 0.593 \\
\hline 2 & 3 & $\begin{array}{c}0.008 \\
(1.41)\end{array}$ & $\begin{array}{r}1.2163 \\
(6.68)\end{array}$ & $\begin{array}{r}1.1068 \\
(5.27)\end{array}$ & $\begin{array}{r}0.2024 \\
(1.04)\end{array}$ & $\begin{array}{r}-0.0819 \\
(-0.97)\end{array}$ & $\begin{array}{r}-0.0946 \\
(-0.32)\end{array}$ & 0.486 \\
\hline 2 & 4 & $\begin{array}{r}0.0028 \\
(0.66)\end{array}$ & $\begin{array}{r}0.8522 \\
(5.98)\end{array}$ & $\begin{array}{r}0.9092 \\
(7.45)\end{array}$ & $\begin{array}{r}0.0677 \\
(0.40)\end{array}$ & $\begin{array}{r}0.0855 \\
(1.09)\end{array}$ & $\begin{array}{r}0.2733 \\
(1.21)\end{array}$ & 0.541 \\
\hline 2 & 5 & $\begin{array}{r}0.0073 \\
(2.23)\end{array}$ & $\begin{array}{r}0.7391 \\
(7.25)\end{array}$ & $\begin{array}{r}0.7111 \\
(7.62)\end{array}$ & $\begin{array}{r}0.1849 \\
(1.58)\end{array}$ & $\begin{array}{r}-0.0443 \\
(-0.62)\end{array}$ & $\begin{array}{r}-0.0455 \\
(-0.33)\end{array}$ & 0.584 \\
\hline 3 & 1 & $\begin{array}{r}0.0027 \\
(0.56)\end{array}$ & $\begin{array}{r}1.1456 \\
(9.46)\end{array}$ & $\begin{array}{c}0.6917 \\
(10.80)\end{array}$ & $\begin{array}{r}-0.3653 \\
(-2.94)\end{array}$ & $\begin{array}{r}0.0219 \\
(0.30)\end{array}$ & $\begin{array}{r}-0.0007 \\
(0.00)\end{array}$ & 0.596 \\
\hline 3 & 2 & $\begin{array}{r}-0.0007 \\
(-0.16)\end{array}$ & $\begin{array}{l}0.921 \\
(8.06)\end{array}$ & $\begin{array}{r}0.6201 \\
(6.61)\end{array}$ & $\begin{array}{r}-0.0387 \\
(-0.31)\end{array}$ & $\begin{array}{r}0.0325 \\
(0.28)\end{array}$ & $\begin{array}{r}0.1717 \\
(1.39)\end{array}$ & 0.552 \\
\hline 3 & 3 & $\begin{array}{r}0.0021 \\
(0.69)\end{array}$ & $\begin{array}{l}0.8667 \\
(11.04)\end{array}$ & $\begin{array}{c}0.4346 \\
(10.54)\end{array}$ & $\begin{array}{r}-0.0012 \\
(-0.01)\end{array}$ & $\begin{array}{r}-0.0695 \\
(-1.30)\end{array}$ & $\begin{array}{r}-0.0222 \\
(-0.24)\end{array}$ & 0.587 \\
\hline 3 & 4 & $\begin{array}{r}0.0065 \\
(2.33)\end{array}$ & $\begin{array}{r}0.7925 \\
(8.47)\end{array}$ & $\begin{array}{r}0.3286 \\
(5.53)\end{array}$ & $\begin{array}{r}0.1358 \\
(1.53)\end{array}$ & $\begin{array}{r}-0.0503 \\
(-1.07)\end{array}$ & $\begin{array}{r}0.03 \\
(0.28)\end{array}$ & 0.470 \\
\hline 3 & 5 & $\begin{array}{r}0.0059 \\
(0.70)\end{array}$ & $\begin{array}{r}0.9206 \\
(6.08)\end{array}$ & $\begin{array}{r}0.5844 \\
(3.08)\end{array}$ & $\begin{array}{r}0.5918 \\
(1.44)\end{array}$ & $\begin{array}{r}0.1228 \\
(0.70)\end{array}$ & $\begin{array}{r}0.3302 \\
(1.64)\end{array}$ & 0.282 \\
\hline 4 & 1 & $\begin{array}{r}-0.0004 \\
(-0.11)\end{array}$ & $\begin{array}{c}0.9352 \\
(11.89)\end{array}$ & $\begin{array}{r}0.3556 \\
(6.91)\end{array}$ & $\begin{array}{r}-0.0828 \\
(-1.40)\end{array}$ & $\begin{array}{r}0.0775 \\
(0.97)\end{array}$ & $\begin{array}{r}0.1129 \\
(1.11)\end{array}$ & 0.569 \\
\hline 4 & 2 & $\begin{array}{r}0.0057 \\
(2.42)\end{array}$ & $\begin{array}{l}0.8936 \\
(13.63)\end{array}$ & $\begin{array}{r}0.2471 \\
(5.86)\end{array}$ & $\begin{array}{r}0.0388 \\
(0.73)\end{array}$ & $\begin{array}{r}-0.0659 \\
(-1.60)\end{array}$ & $\begin{array}{r}0.0495 \\
(0.63)\end{array}$ & 0.597 \\
\hline 4 & 3 & $\begin{array}{r}0.0037 \\
(1.98)\end{array}$ & $\begin{array}{c}0.7929 \\
(14.92)\end{array}$ & $\begin{array}{r}0.2245 \\
(7.12)\end{array}$ & $\begin{array}{r}-0.0066 \\
(-0.13)\end{array}$ & $\begin{array}{r}-0.0897 \\
(-2.66)\end{array}$ & $\begin{array}{r}0.0315 \\
(0.48)\end{array}$ & 0.661 \\
\hline 4 & 4 & $\begin{array}{r}0.0108 \\
(4.89)\end{array}$ & $\begin{array}{l}0.6971 \\
(13.84)\end{array}$ & $\begin{array}{r}0.0974 \\
(2.86)\end{array}$ & $\begin{array}{r}0.0193 \\
(0.33)\end{array}$ & $\begin{array}{l}-0.108 \\
(-2.90)\end{array}$ & $\begin{array}{r}0.0979 \\
(1.41)\end{array}$ & 0.501 \\
\hline 4 & 5 & $\begin{array}{r}0.0094 \\
(2.34)\end{array}$ & $\begin{array}{r}0.7863 \\
(5.97)\end{array}$ & $\begin{array}{r}0.0976 \\
(1.94)\end{array}$ & $\begin{array}{r}0.2394 \\
(2.09)\end{array}$ & $\begin{array}{r}-0.0632 \\
(-0.95)\end{array}$ & $\begin{array}{r}0.0636 \\
(0.43)\end{array}$ & 0.261 \\
\hline 5 & 1 & $\begin{array}{c}0.002 \\
(1.17)\end{array}$ & $\begin{array}{c}0.9284 \\
(20.43)\end{array}$ & $\begin{array}{r}0.0015 \\
(0.06)\end{array}$ & $\begin{array}{r}-0.0927 \\
(-2.91)\end{array}$ & $\begin{array}{r}0.0864 \\
(2.96)\end{array}$ & $\begin{array}{r}0.0095 \\
(0.18)\end{array}$ & 0.709 \\
\hline 5 & 2 & $\begin{array}{r}0.0044 \\
(3.74)\end{array}$ & $\begin{array}{l}1.0515 \\
(29.67)\end{array}$ & $\begin{array}{r}-0.0319 \\
(-1.42)\end{array}$ & $\begin{array}{l}-0.051 \\
(-1.94)\end{array}$ & $\begin{array}{r}-0.0213 \\
(-0.99)\end{array}$ & $\begin{array}{r}-0.0026 \\
(-0.07)\end{array}$ & 0.853 \\
\hline 5 & 3 & $\begin{array}{r}0.0083 \\
(4.91)\end{array}$ & $\begin{array}{r}0.986 \\
(25.48)\end{array}$ & $\begin{array}{r}-0.0706 \\
(-2.93)\end{array}$ & $\begin{array}{r}0.0674 \\
(2.14)\end{array}$ & $\begin{array}{r}-0.0455 \\
(-1.24)\end{array}$ & $\begin{array}{r}0.0142 \\
(0.27)\end{array}$ & 0.761 \\
\hline 5 & 4 & $\begin{array}{r}0.0049 \\
(1.87)\end{array}$ & $\begin{array}{l}1.1237 \\
(15.37)\end{array}$ & $\begin{array}{r}-0.0531 \\
(-1.49)\end{array}$ & $\begin{array}{r}0.2551 \\
(3.30)\end{array}$ & $\begin{array}{r}-0.0097 \\
(-0.24)\end{array}$ & $\begin{array}{r}0.0524 \\
(0.68)\end{array}$ & 0.647 \\
\hline
\end{tabular}




\begin{tabular}{ccrrrrrrr}
\hline Size & $B / M$ & \multicolumn{1}{c}{$\mathrm{a}_{\mathrm{p}}$} & \multicolumn{1}{c}{$\mathrm{b}_{\mathrm{p}}$} & \multicolumn{1}{c}{$\mathrm{s}_{\mathrm{p}}$} & \multicolumn{1}{c}{$\mathrm{h}_{\mathrm{p}}$} & \multicolumn{1}{c}{$\mathrm{m}_{\mathrm{p}}$} & \multicolumn{1}{c}{$\mathrm{d}_{\mathrm{p}}$} & \multicolumn{1}{c}{$\operatorname{Adj} \mathrm{R}^{2}$} \\
\hline 5 & 5 & 0.0054 & 0.9226 & 0.0941 & 0.415 & -0.0745 & -0.1813 & 0.354 \\
& $(1.22)$ & $(7.86)$ & $(1.79)$ & $(4.49)$ & $(-1.48)$ & $(-1.19)$ & \\
\multicolumn{1}{l}{ Average } & & & & & & & 0.556 \\
\hline
\end{tabular}

This table reports the results of individual regressions of a difference of opinion augmented Carhart model on 25 size- and B/M-sorted portfolios for the period 1990 to 2005. The SMB and HML portfolios are created following the methodology employed by Fama and French (1993), and the MOM factor is created following Carhart (1997). The proxy used for the difference of opinion factor (DOF) is dispersion in analysts' earnings forecasts. $b_{p}$ is the factor loading on the market portfolio. $s_{p}$ is the factor loading for SMB. $h_{p}$ is the factor loading for HML. $m_{p}$ is the factor loading for MOM and $d_{p}$ is the factor loading for DOF. 
Table 5

Generalized Method of Moments (GMM) System Tests of the Asset Pricing Models

\begin{tabular}{|c|c|c|c|c|c|c|c|}
\hline & GMM & $\lambda_{\mathrm{m}}$ & $\lambda_{\mathrm{SMB}}$ & $\lambda_{\mathrm{HML}}$ & $\lambda_{\mathrm{MOM}}$ & $\lambda_{\mathrm{DOF}}$ & $\begin{array}{l}\text { MLRT, } \\
\mathrm{H}_{0}: \mathrm{d}_{\mathrm{p}}=0\end{array}$ \\
\hline FF & $\begin{array}{r}33.45 \\
(0.120)\end{array}$ & $\begin{array}{r}0.0046 \\
(2.44)\end{array}$ & $\begin{array}{r}0.0372 \\
(8.15)\end{array}$ & $\begin{array}{r}0.0061 \\
(2.64)\end{array}$ & & & \\
\hline Carhart & $\begin{array}{r}33.89 \\
(0.110)\end{array}$ & $\begin{array}{r}0.0035 \\
(1.90)\end{array}$ & $\begin{array}{r}0.0337 \\
(7.31)\end{array}$ & $\begin{array}{r}0.0079 \\
(3.66)\end{array}$ & $\begin{array}{r}0.0113 \\
(3.47)\end{array}$ & & \\
\hline Carhart DOF (DAF) & $\begin{array}{r}34.20 \\
(0.104)\end{array}$ & $\begin{array}{r}0.0034 \\
(1.77)\end{array}$ & $\begin{array}{r}0.0335 \\
(7.26)\end{array}$ & $\begin{array}{r}0.0077 \\
(3.66)\end{array}$ & $\begin{array}{r}0.0115 \\
(3.49)\end{array}$ & $\begin{array}{r}-0.0043 \\
(-2.17)\end{array}$ & $\begin{array}{l}0.249 \\
(1.00)\end{array}$ \\
\hline $\begin{array}{l}\text { Carhart DOF } \\
\text { (DAF-June) }\end{array}$ & $\begin{array}{r}34.24 \\
(0.103)\end{array}$ & $\begin{array}{r}0.0034 \\
(1.80)\end{array}$ & $\begin{array}{r}0.0328 \\
(7.41)\end{array}$ & $\begin{array}{r}0.0078 \\
(3.75)\end{array}$ & $\begin{array}{r}0.0121 \\
(3.63)\end{array}$ & $\begin{array}{r}-0.0089 \\
(-4.19)\end{array}$ & $\begin{array}{l}0.434 \\
(0.99)\end{array}$ \\
\hline Carhart DOF (AT) & $\begin{array}{r}34.31 \\
(0.101)\end{array}$ & $\begin{array}{r}0.0044 \\
(2.36)\end{array}$ & $\begin{array}{r}0.0328 \\
(7.10)\end{array}$ & $\begin{array}{r}0.0080 \\
(3.58)\end{array}$ & $\begin{array}{r}0.0108 \\
(3.30)\end{array}$ & $\begin{array}{r}0.0016 \\
(0.87)\end{array}$ & $\begin{array}{l}1.743 \\
(0.02)\end{array}$ \\
\hline
\end{tabular}

The test of the difference of opinion augmented Carhart model is based on the following system:

$$
\begin{aligned}
r_{p t}=b_{p} r_{m t}+s_{p} S M B_{t}+ & h_{p} H L_{t}+m_{p} M O M_{t}+d_{p} D D O F_{t}+\varepsilon_{p t}[p=1,2, \ldots, N] \\
r_{m t} & =\lambda_{m}+\varepsilon_{b t} \\
S M B_{t} & =\lambda_{S M B}+\varepsilon_{s t} \\
\mathrm{HML}_{t} & =\lambda_{H M L}+\varepsilon_{\mathrm{ht}} \\
\mathrm{MOM}_{t} & =\lambda_{\mathrm{MOM}}+\varepsilon_{\mathrm{mt}} \\
\mathrm{DOF}_{\mathrm{t}} & =\lambda_{\mathrm{DOF}}+\varepsilon_{\mathrm{dt}}
\end{aligned}
$$

The generalised method of moments (GMM) test statistic, testing that the asset pricing models hold, is distributed as a chi-square with $\mathrm{N}$ degrees of freedom. The statistic has had the small sample adjustment applied following MacKinlay and Richardson (1991). The associated $p$-value is contained in parentheses below the GMM statistic. The associated $t-$ statistic for the factor premiums is contained in parentheses below the coefficient estimates. The Modified Likelihood Ratio Test (MLRT), testing that the 25 coefficients on DOF are jointly equal to zero, has an $\mathrm{F}$ distribution with $(25,162)$ degrees of freedom for the DOF augmented Carhart model. The associated $p$-value is reported below the MLRT statistic in parentheses. The test period is from 1990 to 2005. 